\title{
CULTURAL HEGEMONY IN CHINUA ACHEBE'S THINGS FALL APART: A POSTCOLONIAL ANALYSIS
}

\author{
Shaymaa Neamah Mohammed ALMKHELIF ${ }^{1}$
}

\section{Istanbul / Türkiye \\ p. 184-191}

Received: $10 / 12 / 2021$

Accepted: $21 / 12 / 2021$

Published: 01/01/2022

This article has been scanned $l$ iThenticat No plagiarism detected

\begin{abstract}
:
The current research paper considers theory of cultural hegemony as reflected in the Nigerian novelist Chinua Achebe's 1958 novel Things Fall Apart. The study aims to examine Achebe's novel as a profound example of cultural hegemony during the colonial era. The novelist exhibits his mother land Nigeria as a culturally hegemonized territory by the English colonizer at that time. The study also presents Antonio Gramsci's theory of cultural hegemony as the main subject in the development of both fields Cultural Studies and Postcolonialism. The research paper is divided into three main sections and a conclusion. The first section shows the development of cultural hegemony as a new theory at the hand of the Italian theorist Antonio Gramsci, who is known for his own perspective of hegemony as a cultural component. Based on Gramsci's theory, the second section examines the significance of cultural hegemony in the fields of Cultural Studies and Postcolonialism. As for the third section, it tackles the theory of cultural hegemony through a selective analysis of Achebe's novel. As far as Things Fall Apart is concerned, the analysis traces the novelist's attempt to expose colonialism as a hegemonic power through an overt portrayal of the cultural struggle between the colonizer and the colonized in Nigeria. Finally, the study ends with a conclusion that sums up the ultimate findings of the research..
\end{abstract}

Key words: Cultural Hegemony, Postcolonialism, Marxism, Cultural Studies, Coercion, Consent.

http://dx.doi.org/10.47832/2717-8293.15.13

1 iD Researcher, Kerbalaa University, Iraq, msc.shaiman@gmail.com, $\underline{\text { https://orcid.org/0000-0002-4900-4016 }}$ 


\section{Antonio Gramsci's Theory of Cultural Hegemony}

Cultural hegemony, in general, refers to the domination of a powerful class over weaker classes through ideological and cultural means. It is usually achieved by social institutions which allow the powerful class to highly influence the values, norms, ideas, beliefs and behavior of the rest of society. In order to understand the concept of cultural hegemony, which has first been developed by the Italian theorist Antonio Gramsci, it is necessary to start with hegemony itself.

Hegemony is often based on the use of political and economic powers by the superior over the inferior. Hegemony has traditionally been defined as a political power, which exists between two or more states. However, Karl Marx extends the traditional view of hegemony to the relations between social classes within the state. Marx maintains that the power of the ruling class is based on economic content in which the class struggle ultimately influences the economic and political systems of the state. While the ruling class is securing its power by the formulation of dominant ideas, the working class may react against the dissemination of hegemonic ideas. As a result, the state becomes unstable economically and politically (Williams, 1977, p.108). However, the Italian theorist Antonio Gramsci modifies Marx's view of hegemony. For Gramsci, hegemony is not only economic and political, but also cultural. He looks at culture as a tool by which the dominating class controls the lower class.

While in prison, Gramsci is writing a series of essays that is known as Prison Notebooks in 1926. In Prison Notebooks Volume 1, Gramsci focuses on how the social, political, economic and cultural conditions contributed to the rise of Fascism as a political force in Italy. He wonders how that political force is entrenched as a dictatorship. By referring to the working people's consent as hegemony, Gramsci examines their consent to the Fascist dictatorship as a new phenomenon in society. Although he mentions the term "hegemony" only once in his essay "Some Aspects of the Southern Question", Gramsci highlights hegemony interestingly (Buttigieg, 1992, p.21). According to Gramsci, it is not only coercion that functions in hegemony, but also consent does (Gramsci,1971, p.156). Accordingly, Gramsci raises "The Southern Question" of why the Italian working class adapted to Benito Mussolini's Fascism. Gramsci seems to be puzzled by the consent of people to Mussolini's tyranny. Mussolini's tyranny extends from the North to the South. Mussolini controls labor and factory owners. He also suppresses the uprising of unions. As such, Prison Notebooks is designed to solve the problem of "The Southern Question". The question centers on bringing the laborers of the Italian North with the peasants of the South to produce a new form of cultural hegemony (Srivastava and Bhattacharya, 2012, p.24). Here, comes the role of ideology in producing the new form of cultural hegemony which is based on consent.

From a Gramscian point of view, ideology is a terrain of principles, practices and dogmas, where the individuals are assigned as social agents. This terrain produces the social agents in order to play economic roles in the level of production as well as in the overall structure of society. For Gramsci, ideology has a Marxist materialistic and constitutional nature since its products, represented by the social agents, are directly influenced by economic and institutional motives. In addition, Gramsci perceives ideology as a battle field where persistent struggles exist when two hegemonic principles confront each other (Mouffe, 1979, pp.185-186). According to Gramsci, the practice of ideology has its own representatives and intellectuals. Intellectuals are responsible for spreading ideology and realizing its moral and intellectual reform. Their role centers on persuading people of their ideological project. They, therefore, employ institutional structures so that they would be able to accomplish their mission. Churches, schools, media and even architecture are all instruments that can be used for the function of ideology. The setting, where these tools are found to produce ideology, is called civil society. For Gramsci, civil society achieves stability when hegemony functions within two types of institutions. The first type uses coercion to preserve people's subordination through the police and military institutions. As for the second type, it preserves people's consent by religious institutions, schools, and media. It is here where ideology manages to produce hegemony, that can be exercised by a certain social group over another (Mouffe, 1979, p.187). Mussolini's ideology is the best example of what Gramsci presents.

Mussolini's ideology plays a central role in the development of people's consent to Fascism. As a matter of fact, Fascism has not precisely been defined, but it is generally 
characterized by the absolute power of the state and rule by a dictator. It is a doctrine of action and thought. Before being a political force, Fascism has first been shaped by ideological thought. Gramsci and Mussolini agree that ideology is a battle field of continuous struggles. This stresses the idea that man should be active. He must conceive life of struggle where permanent peace has no place. Accordingly, Fascist ideology is a system of education where people learn how to run a battle (Mussolini, 1935, p.237). However, Mussolini disagrees with Gramsci's understanding of the nature of ideology. Ideology, from a Gramscian perspective, has a Marxist materialistic and constitutional nature. Yet, Mussolini develops an ideology that embodies a rather spiritual thought than materialistic one. $\mathrm{He}$ states that the Italians should grasp Fascism as a new way of life. Culture, as known, is usually referred to as a new way of life. So, Mussolini's description of Fascism as a new way of life suggests the establishment of a new culture in Italy. In order to make this new culture or way of life survive, Mussolini, thereby, refuses the materialistic body of Marxism and substitutes it by religious spirituality. He, therefore, embraces "holiness" and "heroism" as reliable bases for his ideology. Mussolini, finally, clarifies that his Fascist state is completely spiritual and moral by nature. As a result, his ideology makes the state a good guarantor of security on both internal and external levels (Mussolini, 1935, pp.238-242). Compared to the Marxist ideology, Mussolini's ideology seems to be triumphant as it brilliantly touches the ethos of the Italian nation in the 1920s.

\section{Importance of Cultural Hegemony to Cultural Studies}

In the 1970s, cultural hegemony has been introduced to the field of cultural studies by Raymond Williams and others. They play an important role in understanding Gramsci's question. Cultural Studies aims to complete what Gramsci has already proposed. In this sense, Cultural Studies gives Gramsci's theory of cultural hegemony a final shape and applies it to other fields. According to Williams' view of Gramsci's work, the answer lies in the fact that hegemony is a concept which goes beyond two vigorous concepts. Williams identifies the two concepts as culture and ideology. Culture is the social process in which people shape their lives. This culture submits to a system of values and meanings that is set to serve the interests of a particular social class (Williams, 1977, p.108).

The theory of hegemony, in general, and cultural hegemony in particular, is of central importance to the development of Cultural Studies. Stuart Hall sheds light on this by saying: "I have said enough to indicate that, in my view, the line in Cultural Studies which attempted to think forward from the best elements in the structuralist and culturalist enterprises, by way of some of the concepts elaborated in Gramsci's work, comes closest to meeting the requirements of the field of study" (Hall, 2018, p.72).

Although Hall believes that Gramsci's contribution is significant in the field of Cultural Studies, he indicates that Gramsci has not offered absolute responses to "the conundrums of theory". Nevertheless, Gramsci at least addresses many of them. Hall refers to the issues which Marxist theory did not resolve. Cultural hegemony is one of them. Hall also confirms that having a "detour through Gramsci" remains inevitable. He specifies the degree of importance of Gramsci's work to Cultural Studies by arguing that British Cultural Studies has learned from Gramsci a thorough record of information about the nature of culture itself and about the importance of questions of class relations to the development of the theory of cultural hegemony. However, while Gramsci still belongs to Marxism, the importance of his work lies in the radical displacement of some Marxist legacies in British Cultural Studies (During, 1999, p.102).

It seems that Gramsci's theory works to the advantage of practice in Cultural Studies. The theory helps the field understand how cultural forms function in any society; either to develop social domination or to provide people with the power of resistance against such domination. From the perspective of Cultural Studies, society is analyzed as a hierarchical and counter set of social relations where the oppression of subordinate classes prevails (Ritzer, and Smart, 2000, p.396). Hence, taking Gramsci's theory of hegemony, and "counter-hegemony" which means resistance, as a base, Cultural Studies seeks to analyze cultural hegemony through the analysis of ruling or hegemonic social and cultural domination. At the same time, the field aims to find "counterhegemonic" forces to struggle and resist the domination of the ruling social and cultural forces (Durham, and Kellner, 2009 , p. xxiv). It is also worthy noting that Williams emphasizes the importance of counter hegemony to the practice of Cultural Studies: "We have then to add to the concept of 
hegemony the concepts of counter-hegemony and alternative hegemony, which are real and persistent elements of practice" (Williams, 1977, p.112).

Moreover, one of the theories that Cultural Studies pays attention to is Postcolonial theory. The major concern of Cultural Studies and Postcolonialism is culture. Postcolonial theory primarily depends on the analysis of literary texts in relation to the historical contexts of Colonialism. Simultaneously, text analysis is pivotal to Cultural Studies. Yet, texts that Cultural Studies deals with include films, music, mass media, fashion, and even photographs.

The interdisciplinarity of Cultural Studies urges the field to deal with the colonial discourse. Cultural Studies admits the British colonial rule throughout the world. Williams confirms that British colonialism achieved a powerful dominance through the penetration of societies and cultures (Williams, 1973, p.280). In postcolonial studies, the concept of dominance and Gramsci's theory of cultural hegemony really matter. Although most of colonial regimes are originally established through military dominance, the colonizer eventually develops a hegemonic regime. Edward Said, for instance, reveals the fact that European colonial power in the East prevails through dominance and consent. Gramsci's theory is vital to Said's study of Orientalism since European powers dominate the East through the manipulation of the Orientals' culture. In Said's opinion, Orientalism itself, as an influential academic field, is a cultural instrument by which the consent of the Oriental colonized can be achieved. Said indicates that Orientalism has been established as an ideology in order to make both the East and the West believe in the importance of civilizing the Oriental people

(Said, 1978, p.42).

Furthermore, Postcolonial theory takes advantage of Gramsci's reflections on the Indian struggle against British Imperialism and his theory of Italian colonialism. Srivastava and Bhattacharya indicate that Gramsci tackles the Indian nationalist struggle against the British colonization under the leadership of Gandhi. He focuses on the relationship between the political struggle and military war, and the influence of this relationship on the design of the state and the civil society respectively. He also argues that Italy can be taken as an example of the colonial relationship on the national level and the international level as well. Italy, as Gramsci sees, is a representative for a national colonization through the domination of the North over the South. He refutes the idea of the "supporting" North and describes the South as a "semi-colonial market" to the North. As for the international level, Gramsci refers to Italy as being both colonized and colonizing. Italy has been divided by external European powers into fragmented territories, such as, the Bourborn Kingdom of the Two Sicilies and the Catholic Church. In addition, he turns the attention to Italy as an imperialistic power.

In this respect, he refers to the Lybian struggle against Italian colonization (Gramsci, 1971, pp.3-4).

\section{Analysis of Things Fall Apart}

Things Fall Apart is written by the Nigerian novelist Chinua Achebe and published in 1958. The novel is meant to show the Igbo culture before and after colonization. The pretext of colonization is the civilizing mission which is supposed to civilize the primitives and modify their culture. The novel summons the focal points of Gramsci's theory of cultural hegemony. As it has been observed earlier, Gramsci theorizes that any regime does not necessarily relies on dominance by force but uses hegemony as a system of control. According to Gramsci, a hegemonic system is established through the willing consent of people. That consent is obtained by the dominant regime through cultural hegemony. Achebe's novel, hence, presents the hegemonic model of consent and coercion that can be found in the relationship between the colonizer and the colonized.

The Igbo society is known for its distinctive social structure which is composed of the Igbo Council of Chiefs. The Council of Chiefs comprises the Igbo Clan Heads of many villages. Each clan consists of families and each family has a leader. Each clan also has its own political and economic system. Nevertheless, the Igbos, as a whole, are unified by their beliefs and traditions. They all believe in ancestors, gods, and goddesses. These beliefs are the main source of their religious and human activities (Ogbaa, 1995, p.21). As soon as the colonizer enters this society, the Igbo culture starts changing. 
As far as the novel is concerned, language and religion are the cultural components that have been penetrated by the British colonizer. Throughout the novel, the colonial regime uses ideological means to convince the colonized that it is at their best interest to believe in the current regime. The colonizer does not force them into following orders. But, it convinces the colonized through religion. As a result, People of Umuofia are divided into two opposite sides. Some of them show consent to the new religion, while others resist it by all means. The British colonizer employs the church as an ideological institution where he teaches the natives Christianity. Looking at the people of Umuofia as primitives, the colonizer deploys the Christian beliefs as a part of their civilizing mission.

The church focuses on those who suffer because of Igbo customs. It wins such outcasts as Nwoye and Nneka. Okonkwo's son Nwoye abandons the Igbo beliefs that caused his brother Ikemefuna to be slaughtered by Okonkwo. As for Nneka, she escapes from her ancestors' beliefs as her twins have been thrown in the forest of evil by the elders: "[She] had had four previous pregnancies and child-births. But each time she had born twins, and they had been immediately thrown away" (Achebe, 1959, p.138). Nneka seems to be content with the new religion that authorizes her to be a mother of twins.

The colonizer establishes cultural hegemony through language as well. Language plays a huge role in stabilizing the colonial power. The colonizer introduces his educational system to the colonized through English. The colonized is ultimately required to learn the new language in order to establish himself in the new emerging society. Ngugi wa Thiong'o, for instance, conveys a personal experience of being a Kenyan who speaks Gikuyu language. His culture is transmitted by the oral stories of ancestors that have been told in the Gikuyu language. But, things suddenly change as he goes to a colonial school where the language of his education is no longer the language of his culture. He describes English as the official vehicle and the magic formula to colonial elitedom. Ngugi Thiong'o explains three roles of language in a living culture. The first role is that language is a code of understanding social roles that introduce people to the modes of production in a given society. The second role is that language is a mode of communication through which people communicate with each other. The third role is that language is a carrier of culture. Language, as a culture, is the collective memory container of people's experience in history (Thiong'o, 1986, pp.11-14).

In Things Falls Apart, Achebe gives voice to the voiceless Africans as he introduces Igbo language as a cultural carrier of Igbo culture. Igbo culture is conveyed in an oral form of proverbs and songs. Proverbs, as Achebe shows, are the core of the Igbo language: "Among the Igbo the art of conversation is regarded very highly and proverbs are the palmoil with which words are eaten" (Achebe,1959, p.11). When Obierika condemns the colonizer's rule, he recalls an Igbo proverb to describe the rapid spread of the colonizer's culture: "As the elders said, if one finger brought oil it soiled the others" (Achebe,1959, p.116). However, the colonizer imposes his own language on the natives. According to the colonizer's mindset, the language of the superior must prevail. The Igbos, for the colonizer, have no language because they are only savages who communicate through an awkward babble of uncouth sounds. As English language manages to penetrate the natives' culture, it profoundly gains the consent of Okonkwo's son Nwoye. He seems to be heavenly overwhelmed by the hymn of Christianity: "It was not the mad logic of the Trinity that captivated him. He did not understand it. It was the poetry of the new religion, something felt in the marrow" (Achebe,1959, p.135). This sort of poetry touches Nwoye's heart because it reminds him of Ikemefuna, who has been sacrificed for the survival of the tribe: "The hymn about brothers who sat in darkness and in fear seemed to answer a vague and persistent question that haunted his young soul" (Achebe,1959, p.135).

In spite of the fact that the colonizer's language wins many natives, a mutual misunderstanding of each other's culture takes place. In the discussion between Okonkwo and Obierika, the latter suggests the impossibility of understanding the customs of Umuofia by the colonizer, who speaks a completely different language: "How can he when he does not even speak our tongue?" (Achebe,1959, p.160). The encounter of English and the Igbo language, therefore, ends with what Homi Bhabha refers to as mimicry. Bhabha points out mockery as an outcome of the natives' attempts to mimic the colonizer's culture. It turns the colonized to be a jester-like performer. Mimicry is usually directed towards undermining the colonizer's cultural superiority (Homi Bhabha, 1994, p.8591). Ajofia's mockery of Mr. Smith is a salient example. The spokesman of the nine ancestors of Umuofia, Ajofia, makes fun of Mr. Smith as the latter shows lack of understanding to Ajofia's salutation. But, the spokesman's attempt to salute in English goes in vain: "Ajofia laughed in his guttural 
voice...'They are strangers...and they are ignorant' " (Achebe,1959, p.171). Obviously, the linguistic difference furthers the cultural gap. A clash of two cultures may also occur due to the lack of communication between the colonizer and the colonized. As Mr. Smith asks the interpreter to tell Okonkwo and his fellows to leave the church, their answer is: "We cannot leave the matter in his hands because he does not understand our customs, just as we do not understand his. We say he is foolish because he does not know our ways, and perhaps he says we are foolish because we do not know his" (Achebe,1959, p.172). So, the ultimate clash between the two cultures stems from the lack of knowledge about the other culture including language.

At the end, the colonizer's system of education succeeds in accomplishing the civilizing mission, for the church teaches the new ideology in a very intelligent way: "The white man is very clever. He came quietly and peaceably with his religion. We are amused at his religion. We were amused at his foolishness and allowed him to stay. Now he has own our brothers, and our clan can no longer act like one. He has put a knife on the things that held us together and we have fallen apart", Obierika said (Achebe,1959, p.160). The ideology of the church becomes the only means through which more outcasts are won in Umuofia: "Before God...there is no slave or free. We are all children of God and we must receive these our brothers" (Achebe,1959, p.144). Yet, the church threateningly stimulates the converters to give up their native religion: "Unless you shave off the mark of your heathen belief I will not admit you in the church", the white missionary said (Achebe,1959, p.145). The Igbo natives start giving up their cultural identity in favor of the new religion. Consequently, they must be excluded from the clan: "the adherents of the new faith were thenceforth excluded from the life and privileges of the clan" (Achebe,1959, p.146). This provokes the spirit of resistance in Umuofia that is represented by Okonkwo.

For Okonkwo, it is an unbearable situation to witness the eradication of ancestors' heritage by the Igbos themselves. The "Roaring Flame" Okonkwo is an emblem of cultural preservation against cultural hegemony. He aggressively reacts against the persistent endeavor to spread Christianity: " 'Answer me,' roared Okonkwo, 'before I kill you!' ... He seized a heavy stick that lay on the dwarf wall and hit him two or three savage blows" (Achebe,1959, p.139). While the colonizer regards the colonized as savages who need to be civilized, Okonkwo views the colonizer's culture as filth: "Let us not reason like cowards...These people are daily pouring filth over us" (Achebe,1959, p.146). Likewise, he deeply mourns his people's contribution to the downfall of their culture: "What is it that has happened to our people? Why have they lost the power to fight?" (Achebe,1959, p.159). Being unconquerable warriors is an essential part of Igbo cultural identity. The Igbo man must cultivate his skills in war and fighting. It is an urgent need for their survival. However, the fearless people of Umuofia ultimately bow to the power of the colonizing ideology.

It is noted that the colonizer achieves control through consent. Nevertheless, coercion is also used only when consent fails. For Gramsci, physical force is used against those who never show consent. He says: "The apparatus of state coercive power which 'legally' enforces discipline on those groups who do not 'consent' either actively or passively. This apparatus is, however, constituted for the whole society in anticipation of moments of crisis of command and direction when spontaneous consent has failed" (Gramsci, 1971, p.12). As the novel tells, the colonizer's use of force contributes to the subordination of the natives. Obierika informs Okonkwo of the military force that has been used against those who refuse to accept the colonial regime willingly in Abame: "Have you not heard how the white man wiped out Abame?" (Achebe,1959, p.159). Now, it is too late for Okonkwo and his fellows to restore their culture again. Similar to his culture, the great Okonkwo falls apart too. By committing suicide, Okonkwo, eventually, becomes a man who deserves to be remembered in one paragraph only: "The story of this man who had killed a messenger and hanged himself would make interesting reading. Perhaps not a whole chapter but a reasonable paragraph, at any rate", the Commissioner said (Achebe,1959, p.187).

\section{Conclusion}

In conclusion, cultural hegemony is the product of an enormous collaboration between ideology and culture. A certain power turns to be culturally hegemonic once ideology manages to penetrate the culture of a specific society. As it has been observed, cultural hegemony occupies a wide range of interest in the field of Cultural Studies and Postcolonial studies as well. Cultural Studies tackles the theory of cultural hegemony according to Antonio Gramsci's perception of hegemony within the Fascist regime of Mussolini. Gramsci's 
theory also functions in Postcolonial theory as colonialism results in cultural hegemony. Most, if not all, of the colonized countries inevitably experience hegemonic domination. Hegemonic powers attack the culture of the colonized in favor of the colonizer's interests. A case in point is Achebe's Things Fall Apart that exposes the British cultural hegemony in Nigeria where Igbo society is subject to be culturally penetrated by the colonizer. At the end, the Igbos collapse and their culture finally falls apart due to cultural hegemony. 


\section{References}

Achebe, Chinua (1959). Things Fall Apart. A Division of Random House, Inc.

Bhabha, K. Homi (1994). The Location of Culture. Routledge.

Buttigieg, Joseph A., ed. (1992). Antonio Gramsci: Prison Notebooks Volume 1. Columbia University Press.

Durham, Meenakshi Gigi and Douglas M. Kellner, ed. (2009). Media and Cultural Studies Key Words. John Wiley and Sons.

During, Simon (1999). The Cultural Studies Reader. Psychology Press.

Gramsci, Antonio (1971). Selections from the Prison Notebooks. Quintin Hoare and Geoffrey Nowell Smith. Eds. and Trans. International Publishers.

Hall, Stuart (2018). "Cultural Studies: Two Paradigms". Essential Essays Vol. 1: Foundations of Cultural Studies, ed. David Morley. Duke University Press.

Mouffe, Chantal, ed. (1979). Gramsci and Marxist Theory. Routledge and Kegan Paul.

Mussolini, Benito (1935). The Doctrine of Fascism. Ardita.

Ogbaa, Kalu (1995). Igbo: Nigeria. The Rosen Publishing Group, Inc..

Ritzer, George, and Barry Smart (2000). Handbook of Social Theory. Sage.

Said, Edward W. (1978). Orientalism. Vintage Books.

Srivastava, Neelam Francesca Rashmi and Baidik Bhattacharya (2012). The Postcolonial Gramsci. Routledge.

Thiong'o, Ngugi wa (1986). Decolonizing the Mind.: The Politics of Language in African Literature. East African Publishers Ltd..

Williams, Raymond (1977). Marxism and Literature. OUP Oxford. (1973). The Country and the City. Oxford University Press. 